\title{
Penyuluhan Tata Cara Penyelenggaraan Jenazah Bagi Generasi Muda di Desa Kerinjing, Kabupaten Ogan Ilir
}

\author{
Ichsan Hamidi ${ }^{1}$, Dirta Pratama Atiyatna ${ }^{1}$, Alghifari Mahdi Igamo ${ }^{1}$ dan Abdul Bashir ${ }^{1}$ * \\ ${ }^{1}$ Fakultas Ekonomi, Universitas Sriwijaya, Sumatera Selatan, Indonesia \\ *Email korespondensi: abd.bashir@fe.unsri.ac.id
}

Info Artikel: Diterima: 19 Agustus 2020; Disetujui: 26 September 2020; Dipublikasi: 16 Oktober 2020

\begin{abstract}
Abstrak: Beberapa hal pokok dalam ajaran Islam yang diwajibkan untuk dilaksanakan sesegera mungkin, yaitu membayar hutang, menikahkan anak perempuan jika telah memenuhi syarat dan sudah meminta untuk dinikahkan, bertobat atas dosa-dosa yang telah dilakukan, dan yang terakhir menyelenggarakan jenazah bagi sesama muslim. Khusus untuk kewajiban menyelenggarakan jenazah saudaranya yang seiman yang meninggal dunia sampai dengan memakamkan jenazah tersebut agar jangan sampai jenazah tersebut sampai terlantar, sehingga jika hal itu terjadi maka semua orang Islam yang ada disekitar jenazah tersebut akan berdosa. Dalam kenyataannya masyarakat desa Kerinjing Kecamatan Tanjung Raja Selatan Kabupaten Ogan Ilir Provinsi Sumatera Selatan mengalami kesulitan dalam mencari penerus untuk melaksanakan penyelenggaraan jenazah, sehingga perlu dilakukannya kaderisasi kepada para remaja di desa ini dengan diadakannya penyuluhan terkait penyelenggaraan jenazah. Metode kegiatan penyuluhan diakukan dengan ceramah, tanya-jawab dan evaluasi Hasil pengabdian menunjukkan bahwa terjadi peningkatan pengetahuan dan pemahaman para remaja masjid terkait tatacara penyelenggaraan jenazah, sehingga menimbulkan kader-kader baru di lingkungan Desa Kerinjing. Melalui peran serta aktif masyarakat desa terutama para remaja masjid maka diharapkan hasilnya bisa berkontribusi terhadap pembangunan perdesaaan itu sendiri terutama pengembangan SDM Desa ini sendiri.
\end{abstract}

Kata kunci: Penyelenggaraan Jenazah; Pemberdayaan Remaja Masjid; Pengembangan Desa

Kutipan:

Hamidi, I., Atiyatna, D.P., Igamo, A.M., Bashir, A. (2020). Penyuluhan Tata Cara Penyelenggaraan Jenazah Bagi Generasi Muda di Desa Kerinjing, Kabupaten Ogan Ilir. Sricommerce: Journal of Sriwijaya Community Services, 1(2): 125-133. DOI: https://doi.org/10.29259/jscs.v1i2.21

\section{PENDAHULUAN}

Ketergesa-gesaan biasa dikatakan dari setan kecuali dalam lima perkara yaitu Merawat dan menyelenggarakan jenazah, menyajikan makanan ketika ada tamu, menikahkan seorang gadis jika sudah bertemu jodohnya, melunasi utang ketika sudah jatuh tempo dan segera bertaubat jika berbuat dosa besar maupun dosa kecil. Merawat dan menyelenggarakan penyelenggaraan jenazah bagi umat Islam hukumnya fardhu kifayah. Apabila telah ada seseorang atau beberapa kelompok orang telah melaksanakan kewajiban tersebut, maka gugurlah sudah kewajiban orang lain untuk melaksanakannya. Sebagaimana diajarkan dalam agama Islam bahwa salah satu di antara masalah penting yang terkait dengan hubungan manusia dengan manusia adalah masalah penyelenggaraan jenazah. Oleh karena itu, agama Islam menaruh perhatian yang sangat serius dalam masalah ini, sehingga hal ini termasuk salah satu kewajiban yang harus dipenuhi oleh masyarakat, khususnya masyarakat Islam (Hartati, 2013).

Syariat Islam mengajarkan bahwa setiap manusia pasti akan mengalami kematian yang tidak pernah diketahui kapan waktunya. Sebagai makhluk sebaik-baik ciptaan Allah SWT dan ditempatkan pada derajat yang tinggi, maka Islam sangat menghormati orang muslim yang telah 
meninggal dunia. Oleh sebab itu, menjelang menghadapi keharibaan Allah SWT orang yang telah meninggal dunia mendapatkan perhatian khusus dari muslim lainnya yang masih hidup. Apabila seseorang telah meninggal dunia, hendaklah seorang dari mahramnya yang paling dekat dan sama jenis kelaminnya melakukan kewajiban yang mesti dilakukan terhadap jenazah, yaitu memandikan, mengkafani, menyembahyangkan dan menguburkannya. Menyelenggarakan jenazah, yaitu sejak dari menyiapkannya, memandikannya, mengkafaninya, menshalatkannya, membawanya ke kubur sampai kepada menguburkannya adalah perintah agama yang ditujukan kepada kaum muslimin sebagai kelompok masyarakat. Apabila perintah itu telah dikerjakan oleh sebahagian mereka sebagaimana mestinya, maka kewajiban melaksanakan perintah itu berarti sudah terbayar (Pulungan et al, 2020).

Agama Islam menganjurkan kepada seluruh umat islam harus mampu melakukan penyelenggaraan jenazah sesuai dengan tuntunan yang telah disampaikan Rasulullah SAW kepada umatnya. Islam mengatakan bahwa penyelenggaraan jenazah akan lebih afdhal apabila dilakukan oleh keluarga terdekatnya, karena dikhawatirkan adanya aib di tubuh jenazah. Jika penyelenggaraannya dilakukan oleh keluarga terdekatnya, adanya aib di tubuh jenazah kemungkinan besarnya tidak akan diceritakan pada orang lain. Walaupun demikian, dalam syariat Islam juga diperbolehkannya orang lain atau orang yang bukan dari anggota keluarga jenazah pada penyelenggaraannya termasuk pada hal memandikan dan mengafani jenazah. Tentunya, jika yang meninggal dua orang tua (ibu dan bapak), melakukan penyelenggaraan jenazahnya akan lebih afdhal dilakukan oleh anaknya sebagai bagian dari birrul walidain. Semenjak kedatangan Islam di muka bumi yang dibawa Nabi Muhammad Saw telah memberikan perhatian yang amat besar bagi pemecahan masalah social yang dihadapi umat (Nata, 2014)

Memperhatikan fenomena yang terjadi di kalangan masyarakat akhir-akhir ini, banyaknya umat Islam yang mengaku beragama Islam tetapi tidak tahu dengan ajaran agamanya termasuk dalam hal penyelenggaraan jenazah. Fenomena itu bagaikan penyakit yang mewabah di kalangan umat Islam, yang tidak hanya di perkotaan tetapi juga di desa-desa. Ketidaktahuan atau ketidakmampuan umat Islam dalam penyelenggaraan jenazah terutama dalam memandikan dan mengafani jenazah dilatarbelakangi dengan alasan mereka yang bermacam-macam. Di antara yang menjadi alasan mereka tidak tahu dan tidak mampu memandikan jenazah dikarenakan ketakutan jika mereka yang memandikan atau mengafani jenazah, akan menghantuinya dan juga karena penyelenggaraan jenazah bisa diupahkan kepada orang lain. Karenanya menyebabkan mereka tidak mencaritahu akan pelaksanaannya (Yasnel, 2018).

Perawatan jenazah yang biasa dilakukan dalam masyarakat memang berbeda-beda tradisinya. Namun hal-hal yang bersifat sunah tentu tidak ada perbedaan. Pandangan inilah yang mendasari perlunya dilakukan upaya peningkatan perawatan jenazah. Secara khusus Nabi memberikan tuntunan dalam perawatan jenazah ini yang meliputi memandikan jenazah, mengkafani, menshalatkan, sampai menguburkannya. Dalam hal ini Nabi tidak memberikan aturan yang rinci, hanya ketentuan umum saja yang mempermudah kita umat Islam untuk mengembangkannya sendiri di tengah masyarakat yang memiliki budaya yang berbeda-beda. Namun secara khusus Nabi juga memberikan rambu-rambu mana yang harus dilakukan dan mana yang tidak boleh dilakukan (Riyadi, 2013)

Desa yang merupakan aspek utama dalam pembangunan nasional Pembangunan desa menjadi prioritas utama kesuksesan pembangunan nasional, sesuai yang diamanatkan Undang Undang Nomor 6 tahun 2014 tentang Desa, bertujuan meningkatkan kesejahteraan dan kualitas hidup masyarakat desa serta penanggulangan kemiskinan melalui: (1) penyediaan kebutuhan dasar; (2) pembangunan sarana dan prasarana; (3) pengembangan potensi ekonomi lokal; dan (4) pemanfaatan SDA-Lingkungan secara keberlanjutan. Provinsi Sumatera Selatan saat ini memiliki 2.852 desa dan akan terus bertambah seiring dengan pemekaran desa di beberapa wilayah (Mukhlis et.al, 2018)

Lokasi terpilih adalah salah satu desa binaan fakultas Ekonomi yaitu Desa Kerinjing. Desa Kerinjing merupakan salah satu dari 241 desa yang ada diwilayah Kabupaten Ogan Ilir dan salah satu dari 19 Desa di wilayah Kecamatan Tanjung Raja yang terletak $7 \mathrm{Km}$ ke arah Barat dari lbu Kota Kecamatan dan $13 \mathrm{Km}$ kearah Timur dari Ibu Kota Kabupaten dan mempunyai luas $\pm 3,00$ 
Km2, Desa Kerinjing terbagi menjadi 2 dusun yang dipimpin oleh masing-masing Kepala Dusun. Adapun batas-batas wilayah Desa Kerinjing adalah sebagai berikut: sebelah Utara berbatasan dengan Desa Jagaraja (Kec. Rantau Panjang), sebelah Selatan berbatasan dengan Desa Tg Dayang (Kecamatan Indralaya Selatan), sebelah Barat berbatasan dengan Desa Suka Raja Baru, Suka Raja Lama, sebelah Timur berbatasan dengan Skonjing (Hamdan et.al, 2020).

Hamidi (2020) mengungkapkan bahwa masyarakat di desa harus bisa menerapkan nilai-nilai agama Islam dengan baik dan meneruskannya kepada penerus generasi, yaitu para pemudapemudi. Hal ini dimaksudkan agar nilai-nilai islam tidak berhenti hanya di para sesepuh desa saja, tetapi juga bisa diterapkan oleh para pemuda-pemudi. Maka dari itu perlu dibentuk remaja masjid agar bisa menerapkan nilai-nilai agama Islam dengan baik. Apabila ini berjalan dengan baik maka akan terciptalah desa dengan suasana yang Islami.

Sasaran kegiatan ini adalah aparat desa, pemuka masyarakat, tokoh agama, pemuda-pemudi remaja msjid yang ada di desa Kerinjing Kecamatan Tanjung Raja Selatan, Kabupaten Ogan Ilir Provinsi Sumatera Selatan. Dipilihnya khalayak sasaran ini karena dianggap mereka adalah unsur masyarakat yang bisa membantu dan menerapkan nilai-nilai agama Islam khususnya dalam penyelenggaraan Jenazah.

\section{STUDI PUSTAKA}

\subsection{Penyelenggaraan Jenazah}

Penyelenggaraan jenazah merupakan perbuatan seorang muslim terhadap seorang muslim lain yang telah meninggal yang terdiri dari memandikan jenazah, mensholati jenazah, mengkafani jenazah dan menguburkan jenazah. Adapun hukum dari menyelenggarakan jenazah adalah fardhu kifayah. Adapun biaya memandikan sampai dengan proses penguburannya diambil dari harta yang meninggal. Namun jika tidak ada maka diambilkan dari orang yang berkewajiban untuk menafkahinya semasa dia hidup. Namun jika tidak ada, maka diambilkan dari bayt al-mal dan bila hal ini juga tidak memungkinkan maka menjadi tanggung jawab orang islam seluruhnya. Hal ini dimaksudkan agar tidak terjadi penundaan didalam penyelenggaraan jenazah dikarenakan tidak adanya harta untuk membiayai proses penyelenggaraan jenazah ini (Riyadi, 2013).

\subsection{Memandikan Jenazah}

Nurdin (2016) mengungkapkan bahwa cara memandikan Jenazah diawali dengan cara jenazah didudukan secara lemah lembut dengan posisi miring kebelakang. Orang yang memandikan meletakan tangan kanan di bahu dengan ibu jarinya pada lekukan tengkuk, dan lututnya menahan punggung jenazah, lalu perut jenazah diurut dengan tangan kiri untuk mengeluarkan kotoran yang ada. Kemudian jenazah ditelentangkan dan kemaluannya dibersihkan dengan tangan kiri yang dibalut dengan perca. Setelah perca diganti, gigi dan lubang hidungnya dibersihkan juga. Dan jangan lupa bahwa disunnahkan mendahulukan yang kanan dari yang kiri didalam memandikan jenazah mulai dari rambut sampai kaki.

Disunnahkan juga menyirami tubuh mayat sebanyak bilangan ganjil: 3,5,7 atau 9. Menyirami dengan air sabun dengan menggosoknya secara perlahan dan merata. Jika dirasa sudah bersih lalu disiram dengan air yang bersih dengan bilangan ganjil juga, lalu disiram dengan air kapur barus atau minyak wangi. Sabda Rasulullah Saw: Dari Ibnu Abbas, la berkata, tatkala laki-laki jatuh dari kendaraannya lalu ia meninggal, sabda Rasulullah, Mandikanlah dia dengan air serta daun bidara (sejenis sabun)."HR Bukhari Dan Muslim

Para ulama sepakat bahwa jenazah laki-laki sebaiknya dimandikan oleh laki-laki dan jenazah perempuan dimandikan oleh perempuan, dan istri boleh memandikan suaminya. Menurut Jumhur ulama si suami juga boleh memandikan istrinya. Menurut riwayat dari Aisyah, Abu Bakar berwasiat kepda Asma" bin "Umaisy agar memandikannya bila ia meninggal dunia. Dalam hal ini ada pendapat yang mengatakan bahwa istri seseorang lebih berhak memandikan jenazahnya dari pada kerabatnya sendiri, karena istri boleh melihat bagia-bagian tubuh yang tidak boleh dilihat oleh orang lain. Dari kelompok keluarga sendiri yang paling berhak untuk memandikan jenazah seoarang laki-laki adalah ayahnya, kakeknya, dan para'ashobahnya secara berurutan, yaitu anak, 
cucu, anak saudara, paman dan lain-lain, kalau ia mengetahui kewajiban mandi serta dapat dipercaya, Kalau tidak, berpindahlah hak itu kepada keluarga yang jauh yang berpengetahuan dan dapat dipercaya. Apabila di tempat jenazah laki-laki hanya ada perempuan yang bukan muhrim, atau pada jenazah perempuan hanya ada laki-laki, maka jenazah itu tidak dimandikan, cukup ditayamumkan saja (Nurdin, 2016).

\subsection{Mengkafankan Jenazah}

Mengkafankan atau membungkus dengan kain putih merupakan fardhu kifayah. Kewajiban mengkafankan dan segala penyelenggaran jenazah, diambil dari harta peninggalan mayat. Apabila jenazah tidak meninggalkan apa-apa atau harta khusus untuk keperluan ini maka yang wajib membiayai adalah orang yang memikul, yang memberi nafkah ketika masih hidup. Jika yang tersebut di atas juga tidak ada, maka dari harta Baitul Mal umat Islam, atau ditanggung oleh kaum muslimin yang mampu untuk mengurusi. Adapun kain kafan untuk jenazah laki-laki terdiri dari 3 (tiga) lembar kain putih. Kain kafan untuk jenazah perempuan terdiri dari 5 (lima) lembar yaitu: kain panjang, baju kurung, kerudung kepala, kain panjang untuk basahan, penutup pingggang hingga kaki. Kain panjang untuk penutup pinggul dan paha, kain kafan untuk anak-anak terdiri dari 1 (satu) lembar kain putih atau 3 (tiga) lembar kain putih. Utamanya kain kafan: kain putih, bersih, suci, sederhana, kuat (Dahlan, 2020).

\subsection{Mensholatkan Jenazah}

Menshalatkan jenazah menjadi kewajiban bersama menshalatkan jenazah setelah jenazah dalam keadaan suci atau setelah dimandikan dengan seorang imam sebagai pemimpinnya disunnahkan dibuat tiga baris berderat ke belakang, dengan empat kali takbir tanpa ruku dan sujud. Shalat jenazah yang dilakukan oleh ratusan orang akan mampu memberikan syafaat bagi si mayit sebagaimana Nabi SAW bersabda: "Jika seorang muslim wafat kemudian di shalatkan oleh lebih dari seratus muslim, maka doa yang dipanjatkan oleh mereka akan memberikan syafa'at bagi si mayit ( HR. Muslim) (Dahlan, 2020).

\subsection{Menguburkan Jenazah}

Apabila dalam perawatan jenazah dirasakan telah cukup, maka sesegera mungkin membawa jenazah ke kuburan untuk dimakamkan. Diusahakan jangan sampai terlalu lama jenazah berada di rumah. Hendaklah dalam rangka mengiringkan jenazah, suasana tetap sepi dan tenang serta dengan berjalan kaki. Pengiring berada di sekitar jenazah, di depan, di belakang, di samping kiri, dan di samping kanan. Dalam pembuatan liang kubur ada dua macam, yaitu: 1) dengan cara yang disebut cempuren, yakni tempat jenazah berada di tengah-tengah liang kubur. 2) Dengan cara yang disebut liang lahat, yakni tempat jenazah berada di luar dinding liang kubur. Panjang liang kubur disesuaikan dengan panjangnya jenazah, lebar kurang lebih $80 \mathrm{~cm}$, dan dalamnya kurang lebih 150 atau $200 \mathrm{~cm}$ (Riyadi, 2013).

\section{METODE}

Metode Kegiatan dilaksanakan dalam bentuk penyuluhan menggunakan ceramah yang memberikan pemahaman tentang pelaksanaan penyelenggaraan jenazah. Kemudian dilanjutkan dengan diskusi dengan membuka sesi tanya jawab seputar kondisi masyarakat serta permasalahan dan solusi terhadap persepsi masyarakat terhadap pelaksanaan penyelenggaraan jenazah, kemudian diakhiri dengan evaluasi pelatihan dengan cara memberikan kesempatan kepada peserta untuk menanggapi pelaksanaan kegiatan yang berhubungan dengan materi kegiatan sebelum dilakukan kegiatan dan setelah dilakukan kegiatan. Juga dipertanyakan apa yang merupakan kebutuhan, apa yang didapat dan apa yang perlu diperbaiki dalam kegiatan ini. Metode ini dilakukan untuk mengidentifikasi masalah yang ada di Desa Kerinjing Kecamatan Tanjung Raja Kabupaten Ogan Ilir Provinsi Sumatera Selatan. 
Sasaran kegiatan ini adalah aparat desa, pemuka masyarakat, tokoh agama dan pemudapemudi remaja masjid yang ada di desa Kerinjing Kecamatan Tanjung Raja Selatan, Kabupaten Ogan Ilir Provinsi Sumatera Selatan sebanyak 30 orang. Dipilihnya khalayak sasaran ini karena dianggap mereka adalah unsur masyarakat yang bisa membantu dan penyelenggaraan jenazah di desa kerinjing. Keterlibatan mahasiswa dalam pelaksanaan kegiatan pengabdian ini sebagai asisten pelatih/ narasumber dan membantu dalam menginventaris umpan balik dari peserta pelatihan. Kegiatan pelatihan ini menjadi ladang bagi mahasiswa untuk menambah ilmu sekaligus menjadi ajang bagi mahasiswa tersebut untuk mengasah keterampilan dan kemampuan komunikasi dengan masyarakat yang berguna bagi mereka saat nanti terjun ke lapangan kerja.

\section{HASIL DAN PEMBAHASAN}

\subsection{Pelaksanaan Kegiatan}

Pelaksanaan pelatihan dilakukan satu hari penuh, dimulai dari pukul 08.00 WIB sampai dengan 15.00 WIB yang diikuti oleh 30 peserta yang terdiri dari perangkat desa, tokoh masyarakat, pemuka agama, pemuda-pemudi remaja masjid. Selama pelaksanaan pelatihan peserta sangat antusias mengikuti setiap tahapan. Hal ini terlihat dari respon peserta pelatihan dan feedback yang mereka diberikan. Pelatihan diawali dengan sambutan dari Kepala Desa Kerinjing, dilanjutkan dengan sambutan oleh ketua Tim dan pembacaan do'a. Acara dilanjutkan dengan perkenalan dan penyampaian materi oleh narasumber internal dan eksternal dari Universitas Islam Negeri Raden Fatah Palembang Ust. Ibnu Rozali, S.Pd dengan durasi waktu lebih kurang dua jam. Setelah itu dilakukan sesi tanya jawab dan diskusi. Beberapa materi yang disampaikan pada pelatihan tersebut antara lain mengenai tata cara memandikan jenazah, mengkafankan jenazah, mensholatkan jenazah dan menguburkan jenazah.

Narasumber internal dan eksternal sendiri adalah orang yang berkompeten dibidangnya, selain sebagai dosen, narasumber juga aktif di berbagai organisasi dan kegiatan masyarakat dalam menyelenggarakan jenazah, sehingga dapat memberikan masukan dan sharing pengalaman kepada peserta. Banyak hal dan pengalaman lapangan yang disampaikan oleh narasumber berdasarkan apa pernah dilakukan dalam beberapa kegiatan yang berkenaan dengan tata cara memandikan jenazah, mengkafankan jenazah, mensholatkan jenazah dan menguburkan jenazah. Hal ini semakin menambah wawasan dan semangat para peserta pelatihan untuk lebih menggali dan mengembangkan potensi yang dimiliki desa mereka untuk pengembangan pembangunan SDM bagi masyarakatnya ke depan.

\subsection{Respon Peserta Pelatihan}

Pelatihan tata cara penyelenggaraan jenazah bagi remaja masjid dan pemuda-pemudi di Desa Kerinjing berlangsung dari pukul 08.00 WIB sampai dengan 15.00 WIB. Tempat yang digunakan adalah masjid desa kerinjing yang menurut hemat kami cukup representatif untuk dijadikan tempat pelatihan, meskipun tidak terlalu luas tetapi cukup nyaman. Pelatihan berjalan lancar dan santai, akan tetapi serius dalam penyampaian. Semua peserta duduk dengan dilengkapi LCD, microphone dan speaker pengeras suara. Adapun dalam prakteknya narasumber langsung mempraktekkan menggunakan alat peraga khusus untuk penyelenggaraan jenazah, baik boneka sebagai peraga jenazah, sampai tempat memandikan jenazah bahkan wangi-wangian yang digunakan dalam menyelenggarakan jenazah digunakan di dalam prakteknya, sehingga masyarakat sangat bisa mendalami dan memahami secara langsung. Dalam pelaksanaannya Aparat desa dan masyarakat sangat membantu dalam penyiapan sarana prasarana pelatihan tersebut.

Antusiasme peserta pelatihan sangat terlihat saat dibuka sesi Tanya jawab seputar masalah penyelenggaraan jenazah. Narasumber menjawab semua pertanyaan yang diajukan dibarengi dengan solusi yang dapat dilaksanakan untuk memcahkan masalah yang timbul. Penyampaian materi dilakukan dengan menggunakan bahasa yang sederhana dan mudah difahami oleh peserta, sehingga pelatihan dan diskusi berjalan lancar dan sesuai dengan tujuan. 


\subsection{Umpan Balik Peserta}

Umpan balik ini merupakan bagian yang penting dari pelatihan tatacara penyelenggaraan jenazah yang tujuannya untuk mengetahui sejauh mana pemahaman serta penilaian peserta tentang materi pelatihan yang diberikan. Umpan balik ini akan digunakan sebagai bahan evaluasi bagi pelaksana pengabdian untuk menyusun roadmap pengabdian berikut.

Dalam sesi umpan balik ini, setiap peserta diminta untuk menyampaikan kesan dan pesan, serta kritik dan saran pelatihan secara langsung. Hal ini dilakukan untuk membiasakan peserta supaya berani tampil dan terbuka dalam menyampaikan apa yang ada di benaknya. Sebagian besar peserta memberikan respon yang positif, terlihat dari beberapa komentar peserta yang menyatakan bahwa materi yang diberikan memberikan wawasan lebih dalam hal merencanakan pembangunan desa mereka, serta dapat membangun semangat untuk memajukan desa mereka. Meski demikian, ada beberapa peserta mengeluhkan cuaca yang panas dan pelaksanaannya yang agak padat. Meski demikian hal tersebut tidak menjadi halangan yang berarti selama pelatihan. Secara umum dapat disimpulkan bahwa peserta pelatihan merespons secara positif pelatihan ini, meskipun ada kendala cuaca dan waktu pelaksanaannya yang padat.

\subsection{Pembahasan}

Pelatihan tata cara penyelenggaraan jenazah sangatlah penting untuk diterapkan di dalam kehidupan bermasyarakat, terutama di pedesaan dikarenakan kurangnya pemahaman masyarakat akan penyelenggaraan jenazah, sehingga dalam pelaksanaanya hanya melibatkan satu atau dua orang saja yang dianggap mengerti tentang penyelenggaraan jenazah, karena hal inilah sangat perlu adanya kaderisasi, khususnya bagi pemuda-pemudi di Desa Kerinjing, agar kedepannya tidak terjadi hambatan dalam menyelenggarakan jenazah dan tidak menghambat prosesnya ketika sesepuh yang biasa mengerjakan tidak ada di lokasi.

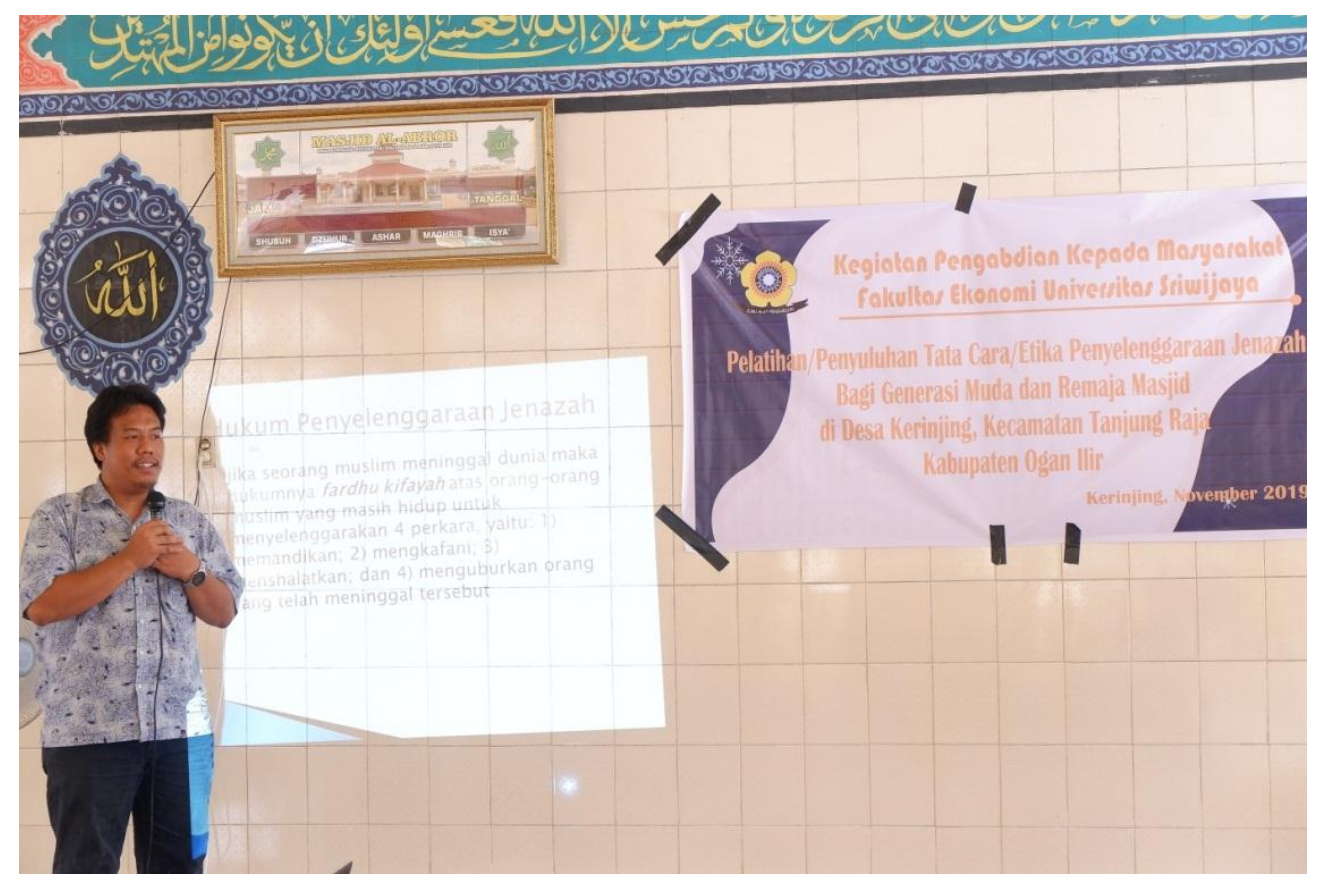

Gambar 1. Pemberian materi oleh narasumber internal

Sumber. Data Primer (2019) 


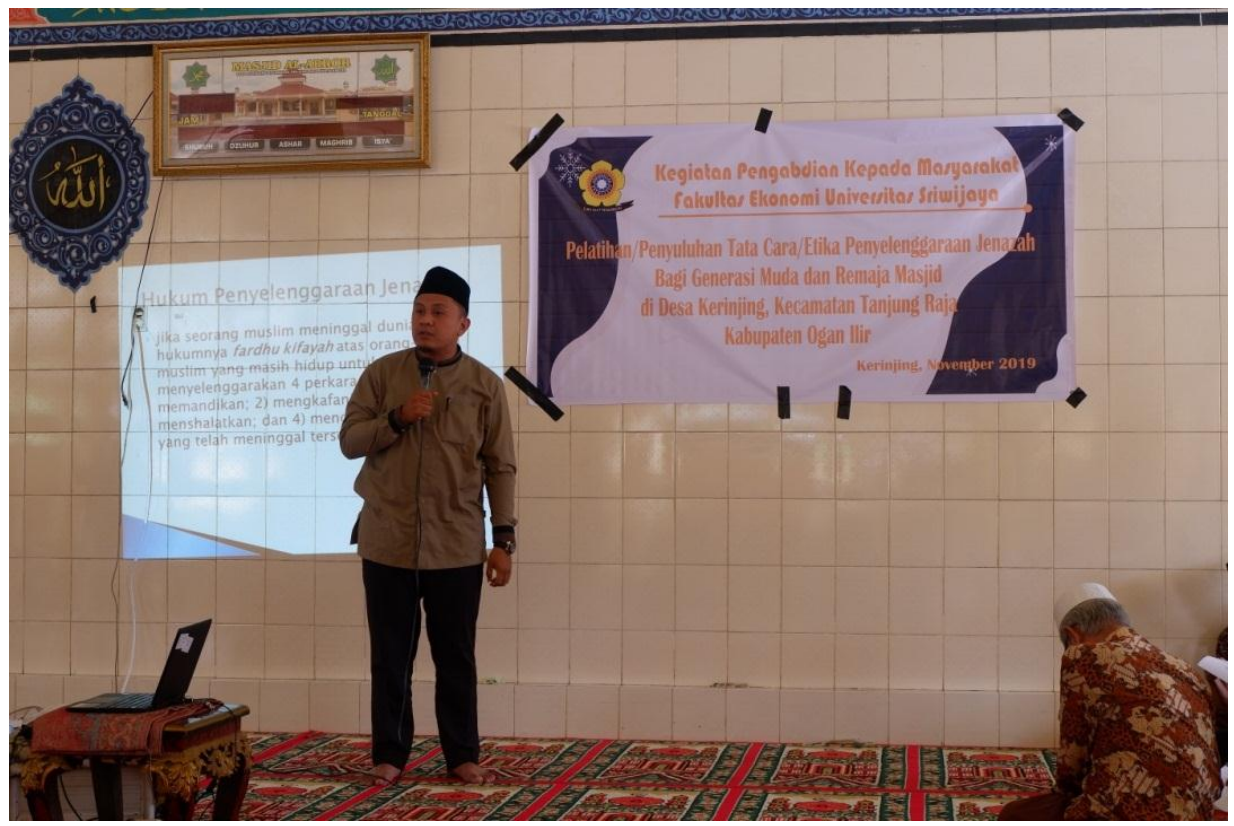

Gambar 2. Pemberian materi oleh narasumber eksternal Sumber. Data Primer (2019)

Dengan adanya pelatihan ini diharapkan masyarakat desa tidak lagi hanya tergantung kepada satu atau dua orang saja dalam hal penyelenggaraan jenazah, akan tetapi semua pihak yang sudah mengikuti pelatihan ini bisa memimpin dan mengarahkan masyarakat yang lain tentang tatacara penyelenggaraan jenazah yang benar. Apabila hal ini bisa tercapai maka tidak menutup kemungkinan masyarakat di Desa Kerinjing, terutama pemuda-pemudinya bisa mengamalkan ilmu ini kepada Desa-desa tentangga, yang mana nantinya bisa menjadi amalan mereka di dunia ini sebagai bekal di akhirat nanti. Karena Agama Islam mengajarkan agar umatnya tidak hanya mengejar kehidupan di dunia akan tetapi juga menyiapkan bekal untuk kehidupan di akhirat nanti.

Pelatihan ini diawali dengan memberikan definisi lebih dalam tentang tatacara penyelenggaraan jenazah, agar masyarakat mengerti dan memahami secara mendalam tentang penyelenggaraan jenazah yang baik dan benar. Kemudian dilanjutkan dengan sesi praktek dengan cara melibatkan para peserta sebagai pelaku dalam menyelenggarakan jenazah sedangkan narasumber memberikan arahan kepada mereka. Hal ini dilakukan tidak lain agar para peserta bisa merasakan secara langsung dan belajar mempraktekkan tentang tatacara penyelenggaraan jenazah yang baik dan benar secara islami.
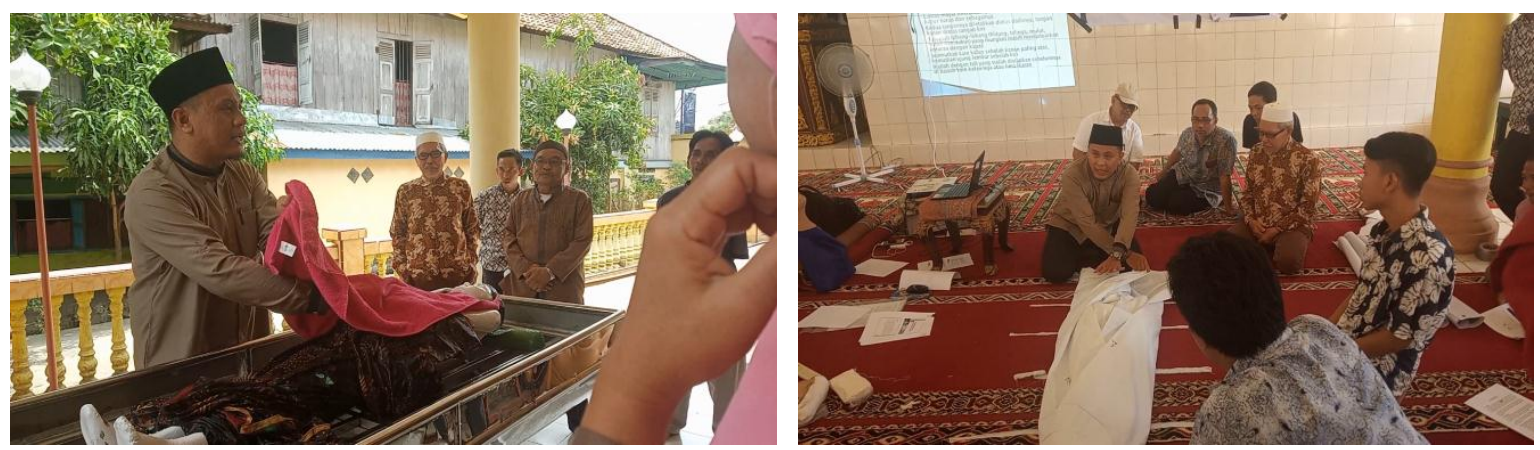

Gambar 3. Pemberian materi dan praktek memandikan dan mengkafankan jenazah Sumber. Data Primer (2019)

Desa kerinjing pada dasarnya memiliki budaya islam yang sangat baik, akan tetapi keterbatasan pemahaman masyarakat tentang tatacara penyelenggaraan jenazah yang benar menyebabkan ketergantungan masyarakat kepada satu atau dua orang yang ahli dalam menyelenggarakan jenazah, sehingga terkadang proses penyelenggaraan jenazah ini menjadi terhambat. 


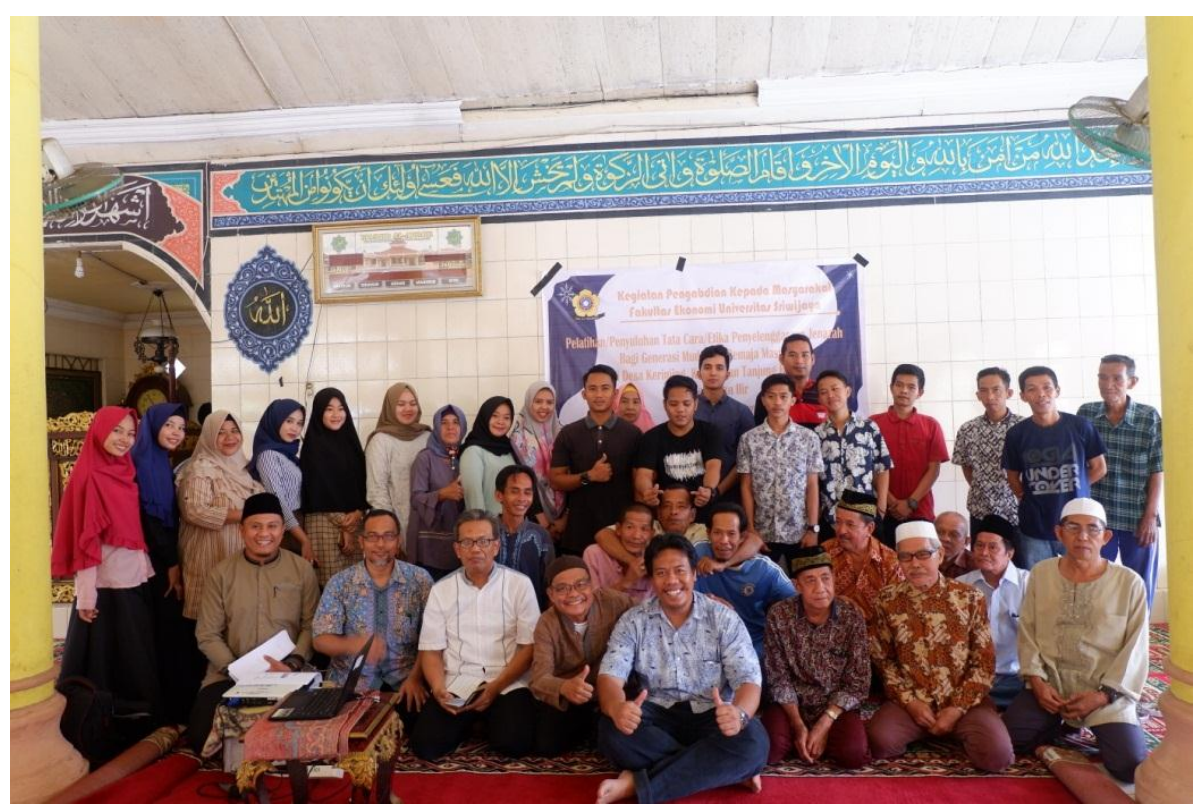

Gambar 4. Penutupan pelaksanaan kegiatan penyuluhan tatacara penyelenggaraan jenazah Sumber. Data Primer (2019)

Maka dari itu pelatihan ini diharapkan bisa menjadi wadah bagi masyarakat untuk belajar dan peduli kepada sesama masyarakat, terutama peduli terhadap umat manusia yang telah terlebih dahulu kembali kepada Allah SWT. Maka kedepannya diharapkan tidak lagi terjadi keterlambatan di dalam menyelenggarakan jenazah di Desa Kerinjing Kecamatan Tanjung Raja Kabupaten Ogan Ilir Provinsi Sumatera Selatan.

\section{KESIMPULAN}

Melalui pelaksanaan pelatihan pelatihan/penyuluhan tata cara/etika penyelenggaraan jenazah bagi generasi muda dan remaja masjid di desa kerinjing, kecamatan tanjung raja kabupaten ogan ilir diharapkan telah mampu memahami penyelenggaraan jenazah yang baik dan benar secara islam, sehingga dalam prakteknya di Desa kerinjing ini bisa melibatkan seluruh aspek masyarakat dan menjadi amal jariah bagi semua pihak yang terlibat dan berpartisipasi dari segala aspek dan saling membantu penyelenggaraan jenazah di Desa Kerinjing.

\section{SARAN}

Dari pelatihan ini masih didapatkan hal-hal yang perlu dilakukan kegiatan pelatihan lanjutan yang lebih bersifat teknis, sehingga dapat dipahami dan dikuasainya secara lebih menyeluruh terkait penyelenggaran jenazah. Juga diharapkan kepada seluruh masyarakat desa, tokoh masyarakat, perangkat desa, dan para pemuda-pemudi di desa kerinjing kabupaten Ogan Ilir untuk lebih aktif lagi mencari informasi dan bila memungkinkan mengikuti acara-acara sosialisasi tentang penyelenggaraan jenazah. Kegiatan pelatihan seperti ini secara berkelanjutan perlu terus dilakukan pada target dan sasaran yang lebih luas lagi, meliputi desa/ kecamatan/ kabupaten lainnya.

\section{UCAPAN TERIMA KASIH}

Kegiatan Pengabdian ini didanai oleh PNBP Fakultas Ekonomi Universitas Sriwijaya. Terima kasih kami ucapkan kepada pihak Fakultas Ekonomi Universitas Sriwijaya, dosen, panitia, mahasiswa dan warga desa yang telah berpartisipasi dalam menyukseskan pelaksanaan kegiatan ini, sehingga bisa berjalan dengan baik dan memberikan manfaat kepada masyarakat Desa Kerinjing. 


\section{REFERENSI}

Dahlan, M. (2020). Membangun Kemandirian Masyarakat Desa dalam Penyelenggaraan Jenazah. JMM (Jurnal Masyarakat Mandiri), 4(1), 29-36. https://doi.org/10.31764/jmm.v4i1.1655.

Hamdan, U., Bakri, S.A., Syathiri, A., \& Tripermata, L. (2020). Penyuluhan tentang Financial Technology di Desa Kerinjing, Kecamatan Tanjung Raja, Kabupaten Ogan Ilir. Sricommerce: Journal Of Sriwijaya Community Services, 1(1), 1-8. doi:https://doi.org/10.29259/jscs.v1i1.4.

Hamidi, I., Bashir, A., Atiyatna, D., Sukanto, S., \& Mukhlis, M. (2020). Pelatihan Manajemen Koperasi Syariah di Desa Kerinjing, Kabupaten Ogan Ilir, Sumatera Selatan. Sricommerce: Journal Of Sriwijaya Community Services, 1(1), 9-16. doi:https://doi.org/10.29259/jscs.v1i1.5.

Hartati. (2013). Pedoman Penyelenggaraan Jenazah. Cetakan 1. Jakarta: Rineka Cipta.

Mukhlis, M.,Sukanto, S., \& Hamidi, I. (2018). Data dan Informasi Manfaat Dana Desa di Provinsi Sumatera Selatan. Jakarta: Badan Penelitian dan Pengembangan, Pendidikan dan Pelatihan, dan Informasi Kementrian Desa, Pembangunan Daerah Tertinggal dan Transmigrasi Republik Indonesia.

Nata, A. (2014) Sosiologi Pendidikan Islam, Cetakan 1. Jakarta: Rajagrafindo Persada.

Nurdin, Z. (2016). Problematika Penyelenggaraan Jenazah di Kota Bengkulu (Studi Analisis Terhadap Persepsi Masyarakat Kota Bengkulu. Manhaj: Jurnal Penelitian dan Pengabdian Masyarakat, 5(1), 79-88.

Pulungan, S., Sahliah, S., Sarudin. S., \& Dharmawati, D. (2020). Peningkatan Keterampilan Pengurusan Jenazah di MTs Ulumul Quran Medan. Qalamuna - Jurnal Pendidikan, Sosial, dan Agama, 12(1), 25-35. https://doi.org/10.37680/qalamuna.v12i01.231.

Riyadi, A. (2013). Upaya Pemberdayaan dan Peningkatan Keterampilan Pemulasaraan Jenazah di Wilayah Kecamatan Mijen Kota Semarang. Dimas: Jurnal Pemikiran Agama untuk Pemberdayaan, 13(2), 201-219. doi:http://dx.doi.org/10.21580/dms.2013.132.43.

Yasnel, Y. (2018). Refleksi Sosial Penyelenggaraan Jenazah bagi Mahasiswa Pendidikan Guru Madrasah Ibtidaiyah. El-Ibtidaiy: Journal of Primary Education, 1(1), 72-89. http://dx.doi.org/10.24014/ejpe.v1i1.5036. 